\title{
Effect of Elevated Carbon Dioxide on the Growth and Physiological Responses of Pineapple, A Species with Crassulacean Acid Metabolism
}

\author{
Jun Zhu' ${ }^{1}$ Duane P. Bartholomew ${ }^{2}$, and Guillermo Goldstein ${ }^{3}$ \\ Department of Agronomy and Soil Science, 1910 East-West Road, and Department of Botany, 3190 Maile \\ Way, University of Hawaii, Honolulu, HI 96822
}

\begin{abstract}
Admitional index words. Ananas comosus, carbon isotope discrimination, chlorophyll fluorescence, Crassulacean acid metabolism, osmolarity, net assimilation rate, relative growth rate, titratable acidity

ABstract. Despite the potential impact of rising global $\mathrm{CO}_{2}$ levels, only a limited number of studies have been conducted on the effects of ambient and elevated $\mathrm{CO}_{2}$ on plants having Crassulacean acid metabolism (CAM). To our knowledge, there are no studies for pineapple [Ananas comosus (L.) Merr.], the most commercially important CAM plant. Pineapple plants were grown at $\mathrm{CO}_{2}$ levels of $\approx 330$ (ambient) and $\approx 730$ (elevated) $\mu \mathrm{mol} \cdot \mathrm{mol}^{-1}$ in open-top chambers for 4 months. The mean air temperature in the chambers was $\approx 39^{\circ} \mathrm{C}$ day $/ 24^{\circ} \mathrm{C}$ night. Average plant dry mass at harvest was $180 \mathrm{~g}$ per plant at elevated $\mathrm{CO}_{2}$ and $146 \mathrm{~g}$ per plant at ambient $\mathrm{CO}_{2}$. More biomass was partitioned to stem and root but less to leaf for plants grown at elevated $\mathrm{CO}_{2}$; leaf thickness was $11 \%$ greater at elevated than at ambient $\mathrm{CO}_{2}$. The diurnal difference in leaf titratable acidity $\left(\mathrm{H}^{+}\right)$at elevated $\mathrm{CO}_{2}$ reached $347 \mathrm{mmol} \cdot \mathrm{m}^{-2}$, which was up to $42 \%$ greater than levels in plants grown in ambient $\mathrm{CO}_{2}$. Carbon isotopic discrimination $(\Delta)$ of plants was $3.75 \%$ at ambient $\mathrm{CO}_{2}$ and $3.17 \%$ at elevated $\mathrm{CO}_{2}$, indicating that $\mathrm{CO}_{2}$ uptake via the $\mathrm{CAM}$ pathway was enhanced more by elevated $\mathrm{CO}_{2}$ than uptake via the $\mathrm{C}_{3}$ pathway. The nonphotochemical quenching coefficient $\left(q_{N}\right)$ of leaves was $\approx 45 \%$ lower in the early morning for plants grown at elevated than at ambient $\mathrm{CO}_{2}$, while afternoon values were comparable. The $\mathrm{q}_{\mathrm{N}}$ data suggested that the fixation of external $\mathrm{CO}_{2}$ was enhanced by elevated $\mathrm{CO}_{2}$ in the morning but not in the afternoon when leaf temperature was $\geq 40{ }^{\circ} \mathrm{C}$. We found no effect of $\mathrm{CO}_{2}$ levels on leaf $\mathrm{N}$ or chlorophyll content. Pineapple dry matter gain was enhanced by elevated $\mathrm{CO}_{2}$, mainly due to increased $\mathrm{CO}_{2}$ dark fixation in environments with day temperatures high enough to suppress $\mathrm{C}_{3}$ photosynthesis.
\end{abstract}

Atmospheric $\mathrm{CO}_{2}$ levels have steadily increased from 275 to $350 \mu \mathrm{mol} \cdot \mathrm{mol}^{-1}$ since the beginning of the industrial revolution (Sarmiento and Bender, 1994), and the $\mathrm{CO}_{2}$ level is predicted to double by the middle of the next century. The growth of many species having the reductive pentose phosphate pathway $\left(\mathrm{C}_{3}\right.$ plants) is significantly increased when the $\mathrm{CO}_{2}$ level is doubled while plants fixing $\mathrm{CO}_{2}$ by the $\mathrm{C}_{4}$-dicarboxylic acid pathway $\left(\mathrm{C}_{4}\right.$ plants) show little or no response when the $\mathrm{CO}_{2}$ level is doubled, (Acock, 1990). This study was designed to investigate the growth and photosynthetic responses of pineapple, a plant having Crassulacean acid metabolism (CAM), to near ambient and elevated $\mathrm{CO}_{2}$ in open-top chambers. We hypothesized that dry matter accumulation would be enhanced, primarily by increased $\mathrm{C}_{3}$ photosynthesis, when plants were grown in elevated $\mathrm{CO}_{2}$.

The environmental physiology of pineapple was recently reviewed (Bartholomew and Malézieux, 1994), and the available data show that the greatest percentage of $\mathrm{CO}_{2}$ is fixed at night. This $\mathrm{CO}_{2}$ is incorporated into $\mathrm{C}_{4}$ acids, primarily malate (Carnal and Black, 1989), followed by massive accumulation in the vacuole (phase I) (Osmond, 1978). The accumulated acids are decarboxylated during the day (phase III), and the released $\mathrm{CO}_{2}$ is incorporated into carbohydrate by the $\mathrm{C}_{3}$ pathway. Once stored acids are depleted, significant quantities of $\mathrm{CO}_{2}$ are assimilated from the air

Received for publication 10 June 1996. Accepted for publication 18 Nov. 1996. Journal series no. 4232 of the Hawaii Institute of Tropical Agriculture and Human Resources, Univ. of Hawaii at Manoa, Honolulu. This research was supported by U.S. Dept. of Agriculture NRI Competitive Grant 93-37100-9480. We thank Frederick Meinzer, Augusto C. Franco, and Robin A. Harrington for their critical reviews of this manuscript. The cost of publishing this paper was defrayed in part by the payment of page charges. Under postal regulations, this paper therefore must be hereby marked advertisement solely to indicate this fact.

${ }^{1}$ Research associate.

${ }^{2}$ Professor, Dept. of Agronomy and Soil Science. To whom requests for reprint should be addressed.

${ }^{3}$ Professor, Dept. of Botany. by the $\mathrm{C}_{3}$ pathway (phase IV). Phase II (Osmond, 1978) in pineapple is a transitory period between phase I and III that occurs at the beginning of the light period.

Gas exchange studies with CAM plants show that elevated $\mathrm{CO}_{2}$ primarily enhances $\mathrm{CO}_{2}$ fixation during phase IV (Nobel and Hartsock, 1986; Szarek et al., 1987), although some species also have increased $\mathrm{CO}_{2}$ uptake (Black, 1986; Nobel and Israel, 1994; Raveh et al., 1995; Winter, 1985) or increased malate accumulation (Nowak and Martin, 1995) during phase I. Only a few studies of the effects of elevated $\mathrm{CO}_{2}$ on CAM plant growth and physiol-

Table 1. Growth responses of pineapple after $123 \mathrm{~d}$ at two $\mathrm{CO}_{2}$ levels in open-top chambers. Data are means of six plants per treatment.

\begin{tabular}{|c|c|c|c|}
\hline \multirow[b]{2}{*}{ Characteristics $^{2}$} & \multicolumn{2}{|c|}{$\mathrm{CO}_{2}$ level $\left(\mu \mathrm{mol} \cdot \mathrm{mol}^{-1}\right)$} & \multirow[b]{2}{*}{$t$ tes } \\
\hline & 330 & 730 & \\
\hline Wt (g/plant) & 146.0 & 180.1 & $* *$ \\
\hline $\mathrm{AL}\left(\mathrm{cm}^{2} /\right.$ plant $)$ & 6404 & 6746 & NS \\
\hline $\operatorname{NAR}\left(\mathrm{g} \cdot \mathrm{m}^{-2} \cdot \mathrm{d}^{-1}\right)$ & 1.64 & 2.23 & $--^{y}$ \\
\hline $\operatorname{RGR}\left(\mathrm{g} \cdot \mathrm{kg}^{-1} \cdot \mathrm{d}^{-1}\right)$ & 7.08 & 8.83 & $--^{y}$ \\
\hline $\operatorname{SMR}(\%)$ & 7.2 & 9.8 & $*$ \\
\hline $\operatorname{RMR}(\%)$ & 8.7 & 11.6 & $* *$ \\
\hline LMR (\%) & 84.1 & 78.7 & $* *$ \\
\hline $\operatorname{SLM}\left(\mathrm{g} \cdot \mathrm{cm}^{-2}\right)$ & 0.019 & 0.021 & $* *$ \\
\hline $\operatorname{dmc}(\mathrm{stem})(\%)$ & 11.20 & 13.12 & $* *$ \\
\hline dmc (leaf) (\%) & 11.35 & 11.21 & NS \\
\hline
\end{tabular}

${ }^{\mathrm{z}} \mathrm{Wt}=$ plant dry mass; $\mathrm{AL}=$ plant leaf area; $\mathrm{NAR}=$ net assimilation rate; $\mathrm{RGR}=$ relative growth rate; $\mathrm{SMR}=$ stem mass/total mass; $\mathrm{RMR}=$ root mass/total mass; LMR = leaf mass/total mass; SLM = specific leaf mass; $\mathrm{dmc}=$ dry matter content. Data for SMR, RMR, and LMR are expressed as the percentage.

y'These growth characteristics were calculated from mean values for plants harvested at the beginning and end of the study so no statistical analysis could be performed.

Ns, ${ }^{* * *}$ Nonsignificant or significant at $P=0.05$ or 0.01 , respectively. 
ogy were found (Cui and Nobel, 1994; Cui et al., 1993; Idso et al., 1986; Nobel and Hartsock, 1986; Raveh et al., 1995), and we could find no studies for pineapple, the most commercially important crop plant having CAM.

Our objectives were to examine the effects of $\mathrm{CO}_{2}$ levels on some growth and physiological aspects of pineapple. The relative contributions of the $\mathrm{C}_{3}$ and CAM pathways to growth were assessed by measuring leaf titratable acidity, leaf osmolarity, and stable carbon isotope discrimination $(\Delta)$. Smaller values indicate enrichment in ${ }^{13} \mathrm{C}$ relative to ${ }^{12} \mathrm{C}$ in leaf tissues, reflecting higher CAM activity, while higher $\Delta$ values indicate relatively greater $\mathrm{C}^{3}$ type activity (Griffiths, 1992). Chlorophyll fluorescence induction kinctics ('Kautsky' effect) were measured during phase II and IV to evaluate the effect of ambient and elevated $\mathrm{CO}_{2}$ levels on photochemical $\left(\mathrm{q}_{\mathrm{p}}\right)$ and nonphotochemical $\left(\mathrm{q}_{\mathrm{N}}\right)$ quenching coefficients and the photochemical efficiency of photosystem II (PSII) (Jones, 1992; Krause, 1991). Such data, which to our knowledge, have not previously been published for pineapple, may help to interpret the results of the effects of environmental factors on plant photosynthesis (Guralnick et al., 1992).

\section{Materials and Methods}

Plant materials and chamber conditions. Thirty fruit tops (crowns) of the Smooth Cayenne pineapple clone Champaka 153 obtained from a local pineapple company were planted in $\approx 4-\mathrm{L}$ pots in 1 black cinder : 1 horticultural vermiculite $(v / v)$ on 1 Jan. 1995. After a 4-month establishment period, six plants of uniform size were selected and placed in each of two open-topped chambers. The number of plants used per treatment was limited by chamber size. The plants were grown with $\mathrm{CO}_{2}$ at $330 \pm 20$ (ambient) and $730 \pm 35$ (elevated) $\mu \mathrm{mol} \cdot \mathrm{mol}^{1}$ from 1 May to 31 Aug. 1995 in a greenhouse at the Univ. of Hawaii at Manoa. The elevated $\mathrm{CO}_{2}$ level was achieved by bleeding pure $\mathrm{CO}_{2}$ through a control valve, flow meter, and tubing into the base of the open-top chamber. The $\mathrm{CO}_{2}$ concentration in the chambers was measured with an IR gas analyzer (Li-6262, LI-COR, Lincoln, Neb.) and the flow rate was adjusted over a few days until the desired set point was reached. The $\mathrm{CO}_{2}$ concentration then was monitored periodically to assure that the elevated $\mathrm{CO}_{2}$ level was maintained at the desired set point.

One month after treatments were started, plants were transferred to $\approx 8-\mathrm{L}$ pots for the remainder of the experiment to assure that rooting volume did not limit growth. Plants were irrigated twice weekly with a nutrient solution specifically developed for pineapple (W.G. Sanford, unpublished data), which consisted of

Table 2. Photochemical $\left(\mathrm{q}_{\mathrm{P}}\right)$ and nonphotochemical $\left(\mathrm{q}_{\mathrm{N}}\right)$ quenching and photochemical efficiency $\left(F_{v}: F_{m}\right)(n=$ six plants) of the youngest physiologically mature leaves of pineapple grown at two $\mathrm{CO}_{2}$ levels in open-top chambers.

\begin{tabular}{lcccc}
\hline & & \multicolumn{2}{c}{$\mathrm{CO}_{2}$ level $\left(\mu \mathrm{mol} \cdot \mathrm{mol}^{-1}\right)$} & \\
\cline { 3 - 4 } Parameters & Phase $^{\prime}$ & 330 & 730 & \multirow{2}{*}{$t$ test } \\
\hline $\mathrm{q}_{\mathrm{p}}$ (morning) & II & 0.727 & 0.841 & NS \\
$\mathrm{q}_{\mathrm{P}}$ (afternoon) & IV & 0.809 & 0.897 & NS \\
$\mathrm{q}_{\mathrm{N}}$ (morning) & II & 0.681 & 0.377 & $*$ \\
$\mathrm{q}_{\mathrm{N}}$ (afternoon) & IV & 0.643 & 0.651 & NS \\
$\mathrm{F}_{\mathrm{v}}: \mathrm{F}_{\mathrm{m}}$ (morning) & II & 0.831 & 0.864 & NS \\
$\mathrm{F}_{\mathrm{v}}: \mathrm{F}_{\mathrm{m}}$ (afternoon) & IV & 0.790 & 0.833 & NS \\
\hline
\end{tabular}

${ }^{2}$ Measured at the beginning (phase II) and end (phase IV) of the light period.

${ }_{\text {Ns, }}{ }^{*}$ Nonsignificant or significant at $P=0.05$, respectively. (in $\mathrm{mm} \cdot \mathrm{L}^{-1}$ ) $0.5 \mathrm{KH}_{2} \mathrm{PO}_{4}, 0.82 \mathrm{MgSO}_{4} \cdot 7 \mathrm{H}_{2} \mathrm{O}, 0.5 \mathrm{~K}_{2} \mathrm{SO}_{4}, 2.5$ $\mathrm{NH}_{4} \mathrm{NO}_{3}$, and $0.5 \mathrm{CaCl}_{2}$ (anhydrous) and (in $\left.\mu \mathrm{M} \cdot \mathrm{L}^{-1}\right) 11.5 \mathrm{H}_{3} \mathrm{BO}_{3}$, $2.3 \mathrm{MnCl}_{2} \cdot 4 \mathrm{H}_{2} \mathrm{O}, 0.3 \mathrm{ZnSO}_{4} \cdot 7 \mathrm{H}_{2} \mathrm{O}, 0.08 \mathrm{CuSO}_{4} \cdot 5 \mathrm{H}_{2} \mathrm{O}, 0.03$ $\mathrm{H}_{2} \mathrm{MoO}_{4} \cdot \mathrm{H}_{2} \mathrm{O}$, and $9.0 \mathrm{Fe}$ as the chelate. Pots were flushed with tap water monthly to prevent nutrients from accumulating in the media.

The two open-top chambers were $1.5 \mathrm{~m}$ long, $1.3 \mathrm{~m}$ wide, and $1.4 \mathrm{~m}$ tall and were constructed of a frame covered with mylar film. A table fan $(\approx 20 \mathrm{~cm}$ in diameter) was used in each chamber to circulate the air. The two chambers were adjacent to each other on one greenhouse bench and perpendicular to the prevailing air flow across the bench. Because air temperature in the chambers was not controllable, they were covered with $30 \%$ neutral-density shade cloth to reduce heat build-up. Air temperatures at the midplant height in the two chambers were measured with thermocouples shaded with aluminum foil. Leaf temperatures were measured periodically by inserting fine-wire thermocouples into the tissuc of the tallest leaf, which is identified by bunching the uppermost leaves on the plant together and selecting the one whose leaf tip extends above all the others. With normal growth the tallest leaf, termed the "D" leaf in the pineapple literature (Bartholomew and Kadzimin, 1977), is about the youngest physiologically mature leaf on the plant. The D leaf has been used to index plant nutrient levels and evaluate the effects of environmental factors on plant growth and water status (Bartholomew and Kadzimin, 1977). All thermocouple data were collected using a datalogger (21X, Campbell Scientific, Logan, Utah). The mean air temperatures inside the chambers during the day (7:30 $\mathrm{AM}$ to $6: 30 \mathrm{PM}$ ) were $39.0^{\circ} \mathrm{C}$ in the ambient and $39.5^{\circ} \mathrm{C}$ in the elevated $\mathrm{CO}_{2}$ treatments, while the mean temperature at night was $24.1^{\circ} \mathrm{C}$ in both chambers. Reducing the radiation load with shadecloth resulted in mean leaf temperatures that were only $\approx 1.0^{\circ} \mathrm{C}$ above mean air temperature. In Hawaii, leaf temperatures of pineapple can be several degrees above air temperature (Noffsinger, 1961), and temperatures as high as $50^{\circ} \mathrm{C}$ have been measured in the field with no physiological injury (Aubert and Bartholomew, 1973). The average midday maximum photosynthetic photon flux (PPF) measured by the quantum sensor (LI-COR) was $\approx 500 \mu \mathrm{mol} \cdot \mathrm{m}^{-2} \cdot \mathrm{s}^{-1}$ at midplant height inside the chambers.

Growth analysis. The mean initial fresh and dry mass of leaves, stems, and roots was calculated from measurements made at the beginning of the experiment on six 4-month-old plants comparable to those used in the study. Final data on the previously described parameters were obtained by destructive harvest of the experimental plants after 4 months of treatment. Dry mass was measured after oven-drying at $70^{\circ} \mathrm{C}$ for 2 weeks. Green leaf area was measured using a leaf area meter (Li-3100; LI-COR). Dry mass partitioning was assessed by calculating the ratios of stem (SMR), root (RMR), or leaf (LMR) to whole-plant dry mass. Relative growth rate (RGR) and net assimilation rate (NAR) (Chiariello et al. 1989) were calculated as described by the following equations:

$$
\begin{aligned}
& \text { RGR }=\frac{\ln w_{2}-\ln w_{1}}{t_{2}-t_{1}} \\
& \text { and } \\
& N A R=\frac{2\left(w_{2}-w_{1}\right)}{\left(A_{2}+A_{1}\right)\left(t_{2}-t_{1}\right)}
\end{aligned}
$$

where $\mathrm{W}$ is total plant dry mass, $\mathrm{A}$ is green leaf area, $\mathrm{t}$ is time, and the subscripts 1 and 2 represent samples collected on 1 May and 31 Aug., respectively. Specific leaf mass (SLM), the leaf dry mass : green leaf area ratio, and tissue dry matter contents also were calculated. 
Carbon isotope niscrimination. Relative natural abundance of the stable carbon isotopes ${ }^{13} \mathrm{C}$ and ${ }^{12} \mathrm{C}\left(\delta^{13} \mathrm{C}\right)$ in leaf tissue was determined on a subsample of the $\mathrm{D}$ leaf. Leaves were oven-dried at $70{ }^{\circ} \mathrm{C}$ and finely ground. The ${ }^{13} \mathrm{C}:{ }^{12} \mathrm{C}$ ratio of the leaf tissue was measured on a SIRA series II isotope ratio mass spectrometer(VG Isotech, Middlewich, U.K.) at the Duke Univ. Phytotron. The ${ }^{13} \mathrm{C}$ $:{ }^{12} \mathrm{C}$ ratio of source air in the chambers was measured by collecting samples in 250-mL pyrex gas collecting tubes. The air samples were analyzed using a mass spectrometer (Finnigan MAT 252; Finnigan Corp., Germany) in the Institute of Geophysics, Univ. of Hawaii. The $\delta^{13} \mathrm{C}$ data were used to calculate carbon isotope discrimination $(\Delta)$ by the following equation:

$\Delta=\frac{\delta_{\mathrm{a}}-\delta_{\mathrm{p}}}{1+\delta_{\mathrm{p}}}$

where "a" is the isotopic composition of air, and "p" is that of the leaves.

ChLorophyll Fluorescence kinEtics. Fluorescence induction kinetics were measured biweekly with a chlorophyll fluorometer (PAM 101; Walz, Effeltrich, Germany) beginning 1 month after starting the $\mathrm{CO}$ treatments. Measurements were made on D leaves at $\approx 8: 00 \mathrm{AM}$ (phase II) and 5:00 PM (near the end of phase IV) when $\mathrm{C}_{3}$-type photosynthesis would be high ( $\left.\mathrm{Zhu}, 1996\right)$. The plants were dark-acclimated for $\approx 30 \mathrm{~min}$, and the fluorescence intensity of the D leaves was detected following the procedure described by Guralnick et al. (1992) and Jones (1992). Leaves were illuminated with modulated light $\left(\mathrm{PPF} \approx 2\right.$ to $\left.4 \mu \mathrm{mol} \cdot \mathrm{m}^{-2} \cdot \mathrm{s}^{-1}\right)$ to induce the initial fluorescence yield $\left(\mathrm{F}_{0}\right)$, followed by a saturating pulse $\left(\mathrm{PPF} \approx 2200 \mu \mathrm{mol} \cdot \mathrm{m}^{-2} \cdot \mathrm{s}^{-1}\right.$ ) to create maximum fluorescence $\left(F_{m}\right.$, dark adapted) and the peak fluorescence [Fm(t), light adapted] and further by actinic light $\left(P P F \approx 350 \mu \mathrm{mol} \cdot \mathrm{m}^{-2} \cdot \mathrm{s}^{-1}\right.$ ) to drive photosynthesis and, thus, increase fluorescence yield. Variable fluorescence $\left(\mathrm{F}_{\mathrm{v}}\right)$ was calculated as $\mathrm{F}_{\mathrm{m}}-\mathrm{F}_{0}$ and the photochemical efficiency of PSII was estimated as $\mathrm{F}_{\mathrm{v}} / \mathrm{F}_{\mathrm{m}}$ (Jones, 1992). The values for $\mathrm{q}_{\mathrm{p}}$ and $\mathrm{q}_{\mathrm{N}}$ were calculated using the equations described by Jones (1992) and Guralnick et al. (1992).

Titratable aCidTTY AND osmolarity. Leaf titratable acidity (TA) and osmolarity were measured on one D leaf from each of six plants per chamber collected at the beginning and end of the light period. The D leaf was split longitudinally and one-half was removed at dawn and frozen at $-75^{\circ} \mathrm{C}$ to disrupt the cell membranes. The second leaf segment was harvested in the late afternoon and similarly frozen. To determine TA, two leaf disks $(1.3 \mathrm{~cm}$ in diameter) were cut from the middle one-third of each frozen leaf segment and ground in a mortar with $20 \mathrm{~mL}$ distilled water; the total volume titrated to $\mathrm{pH} 7.2$ using $0.01 \mathrm{~N} \mathrm{NaOH}$. Osmolarity was measured on leaf sap extracted from frozen-thawed tissues with a vapor pressure osmometer (5500S, Wescor, Logan, Utah).

ChLOROPHYLL AND N ConTENTS. Leaf chlorophyll content was determined on 1.3-cm disks from the middle one-third of the D leaf preserved by freezing as previously described. The frozen disks were ground to a powder in liquid $\mathrm{N}$, and a $200-\mathrm{mg}$ sample was extracted by grinding it with $80 \%(\mathrm{v} / \mathrm{v})$ acetone, which was brought to a final volume of $20 \mathrm{~mL}$ with $80 \%$ acetone. The mixture was incubated overnight at room temperature $\left(22^{\circ} \mathrm{C}\right)$ and centrifuged at $12000 \times \mathrm{g}$ for $1 \mathrm{~min}$, and the absorbance of the supernatant was read at 647-and 664-nm wavelengths with a spectrophotometer (Spectronic 21, Bausch \& Lomb, New York). Chlorophyll content was calculated according to Coombs et al. (1985).

Leaf total $\mathrm{N}$ content was determined using the same leaf tissue powder used for the chlorophyll measurement by the microkjeldahl technique at the Agricultural Diagnostic Service Center,
Table 3. Titratable acidity (TA) and osmolarity of the youngest physiologically mature leaves ( $\mathrm{n}=$ six plants) of pineapple grown at two $\mathrm{CO}_{2}$ levels in open-top chambers.

\begin{tabular}{|c|c|c|c|c|}
\hline \multirow[b]{2}{*}{ Characteristics } & \multirow[b]{2}{*}{ Phase $^{\mathrm{z}}$} & \multicolumn{2}{|c|}{$\begin{array}{c}\mathrm{CO}_{2} \text { level } \\
\left(\mu \mathrm{mol} \cdot \mathrm{mol}^{-1}\right)\end{array}$} & \multirow[b]{2}{*}{$t$ tes } \\
\hline & & 330 & 730 & \\
\hline \multicolumn{5}{|c|}{$\mathrm{TA}, \mathrm{H}^{+}\left(\mathrm{mmol} \cdot \mathrm{m}^{-2}\right)$} \\
\hline 30 June 1995 & I & 225.5 & 293.2 & ** \\
\hline 31 Aug. 1995 & I & 278.2 & 384.3 & $* *$ \\
\hline 30 June 1995 & IV & 31.6 & 32.9 & $*$ \\
\hline 31 Aug. 1995 & IV & 35.4 & 37.4 & $*$ \\
\hline \multicolumn{5}{|l|}{$\Delta \mathrm{TA}^{\mathrm{y}}$} \\
\hline 30 June 1995 & & 194.0 & 260.3 & $* *$ \\
\hline 31 Aug. 1995 & & 242.8 & 347.0 & $* *$ \\
\hline \multicolumn{5}{|c|}{ Osmolarity $\left(\mathrm{mmol} \cdot \mathrm{kg}^{-1}\right)$} \\
\hline 31 Aug. 1995 & I & 418.4 & 504.5 & $* *$ \\
\hline 31 Aug. 1995 & IV & 441.2 & 484.0 & * \\
\hline
\end{tabular}

${ }^{2}$ Measured at the end of the dark (phase I) and light (phase IV) periods. 'Difference between TA in phase I and IV.

${ }^{* * * *}$ Significant at $P=0.05$, or 0.01 , respectively.

Univ. of Hawaii at Manoa. The data were reported as the percentage $\mathrm{N}$ in the leaf on a dry mass basis $(\mathrm{m} / \mathrm{m}$, percent).

\section{Results and Discussion}

Mean D leaf temperature during the study was $40.4^{\circ} \mathrm{C}$ day $/ 23.9$ ${ }^{\circ} \mathrm{C}$ night in elevated and $40.0^{\circ} \mathrm{C}$ day $/ 24.2^{\circ} \mathrm{C}$ night in the ambient $\mathrm{CO}_{2}$ chambers. Despite the high average day temperature, growth was normal, and there was no evidence of heat injury to the plants. The leaf temperatures that we encountered also occur in the field in Hawaii (Aubert and Bartholomew, 1973).

Biomass accumulation over the 4-month growing period was significantly greater at elevated than at ambient $\mathrm{CO}_{2}$ (Table 1). This result confirmed those of a previous study (Zhu, 1996) where pineapple dry mass of plants grown 6 months in controlled environments at $30^{\circ} \mathrm{C}$ day $/ 20^{\circ} \mathrm{C}$ night, $30{ }^{\circ} \mathrm{C}$ day $/ 25^{\circ} \mathrm{C}$ night, and $35^{\circ} \mathrm{C} / 25^{\circ} \mathrm{C}$ night was $23 \%$ to $42 \%$ greater at $700 \mu \mathrm{mol} \cdot \mathrm{mol}^{-1} \mathrm{CO}_{2}$ than at $350 \mu \mathrm{mol} \cdot \mathrm{mol}^{-1}$. However, the $\mathrm{CO}_{2}$ treatments in that study were conducted at different times because only three controlled environment chambers were available. There also was enhanced plant growth at elevated $\mathrm{CO}_{2}$ for the CAM species Agave deserti Engelm. and Ferocactus acanthodes (Lem.) Britt. and Rose (Nobel and Hartsock, 1986), Agave vilmoriniana A. Berger (Idso et al., 1986), and Opuntia ficus-indica (L.) Mill. (Cui and Nobel, 1994; Cui et al., 1993).

The mean RGR and NAR values also were higher for plants grown at elevated than at ambient $\mathrm{CO}_{2}$. Since mean plant leaf areas in the two treatments were not significantly different (Table 1), we conclude that the growth response to elevated $\mathrm{CO}_{2}$ was due to the greater NAR. The mean NAR value for plants grown in ambient $\mathrm{CO}_{2}$ in this study was $\approx 20 \%$ greater than those obtain in controlled environments (Zhu et al., 1996), while the NAR value at elevated $\mathrm{CO}_{2}$ in this study was $\approx 8 \%$ smaller than that obtained previously (Zhu, 1996). This result indicates that plant growth in this study was not suppressed by the high daytime temperature. Our results also are consistent with previous studies of leaf gas exchange ( $\mathrm{Zhu}$, 1996) that showed that elevated $\mathrm{CO}_{2}$ significantly enhanced diurnal $\mathrm{CO}_{2}$ fixation. No $\mathrm{CO}_{2}$ exchange data were obtained for this study because equipment to continuously measure $\mathrm{CO}_{2}$ exchange rates of pineapple leaves was unavailable and attempts to seal a 
portable leaf chamber on the sharply curved pineapple leaves were unsuccessful.

At elevated $\mathrm{CO}_{2}$, more biomass was partitioned to root and stem and less to leaf, thus accounting for the significantly greater fraction of plant biomass incorporated into stem (SMR) and root (RMR) and the smaller portion partitioned to leaf (LMR) (Table 1). Leaf thickness (SLM) was significantly greater at elevated than at ambient $\mathrm{CO}_{2}$ (Table 1). Cladodes of the CAM species O. ficusindica also were thicker when plants were grown at elevated $\mathrm{CO}_{2}$ (Nobel and Israel, 1994). Stem dry matter content was significantly greater for plants grown at elevated than at ambient $\mathrm{CO}_{2}$, but there was no effect on the leaf dry matter content (Table 1). Pineapple stem dry matter and starch contents are positively correlated (Bartholomew and Paull, 1986). Thus, the greater stem dry matter content may be due in part to greater stem starch content at elevated $\mathrm{CO}_{2}$.

The $\mathrm{q}_{\mathrm{p}}$ values of plants grown at elevated $\mathrm{CO}_{2}$ were not significantly higher than those for plants grown at ambient $\mathrm{CO}_{2}$ (Table 2). During phase II, the $\mathrm{q}_{\mathrm{N}}$ values for plants grown at high $\mathrm{CO}_{2}$ averaged $45 \%$ less than for plants grown at ambient $\mathrm{CO}_{2}$, but the values during phase IV were similar (Table 2). High rates of $\mathrm{CO}_{2}$ fixation result in lower $\mathrm{q}_{\mathrm{N}}$ and higher $\mathrm{q}_{\mathrm{p}}$ values because the $\mathrm{pH}$ gradient across the thylakoid membranes is low due to faster consumption of ATP and NADPH (Guralnick et al., 1992). Thus the $\mathrm{q}_{\mathrm{N}}$ and $\mathrm{q}_{\mathrm{p}}$ data obtained in this study indicate that the fixation of external $\mathrm{CO}_{2}$ via the $\mathrm{C}_{3}$ pathway was significantly greater for pineapple plants grown at elevated $\mathrm{CO}_{2}$ in phase II but not in phase IV. In other studies with pineapple at day temperatures of $\leq 35^{\circ} \mathrm{C}$, net $\mathrm{CO}_{2}$ assimilation via the $\mathrm{C}_{3}$ pathway occurred mainly in phase IV (Bartholomew, 1982; Cote et al., 1993; Zhu, 1996), and uptake during that phase was significantly enhanced in elevated $\mathrm{CO}_{2}$ (Zhu, 1996). The lack of any effect of $\mathrm{CO}_{2}$ level on $\mathrm{q}_{\mathrm{N}}$ or $\mathrm{q}_{\mathrm{p}}$ in phase IV in our study made it appear likely that $\mathrm{CO}_{2}$ uptake during this phase was suppressed, possibly by the high day temperature prevailing in this study. The $\mathrm{F}_{\mathrm{v}}$ and $\mathrm{F}_{\mathrm{m}}$ values at elevated $\mathrm{CO}_{2}$ were slightly but not significantly greater than those at ambient $\mathrm{CO}_{2}$ in

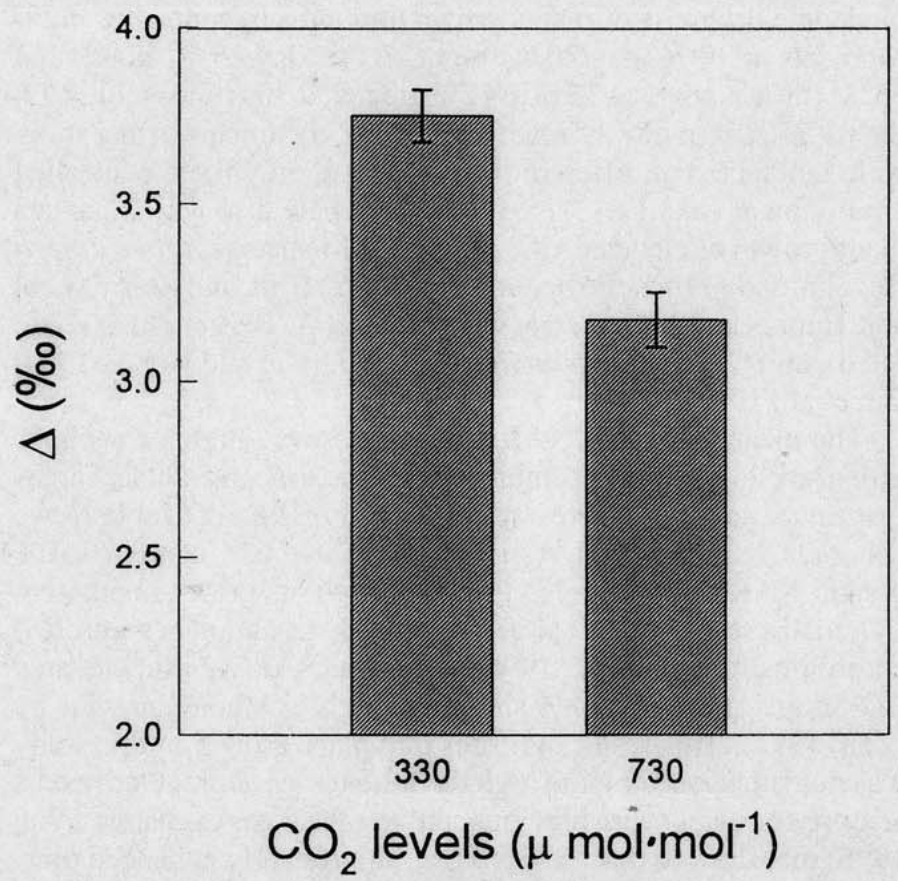

Fig. 1. Carbon isotopic discrimination $(\Delta)$ of the youngest physiologically mature leaf of pineapple grown at two $\mathrm{CO}_{2}$ levels in open-top chambers. phase II and IV (Table 3), indicating that the photochemical efficiency of plants grown at ambient $\mathrm{CO}_{2}$ (Fig. 1) was significantly greater than that for plants grown at elevated $\mathrm{CO}_{2}$. The assimilation of a greater fraction of the $\mathrm{CO}_{2}$ via the $\mathrm{C}_{3}$ pathway by plants grown at ambient $\mathrm{CO}_{2}$ in this study is in contrast to the results obtained in an earlier growth-chamber study with day temperatures of $\leq 35^{\circ} \mathrm{C}$ (Zhu, 1996). In that study, the $\Delta$ values of D-leaf tissue from plants grown in elevated $\mathrm{CO}_{2}$ were significantly greater than those for plants grown at ambient $\mathrm{CO}_{2}$ ( $\left.\mathrm{Zhu}, 1996\right)$. The $\Delta$ values for our study indicate that at an average day temperature near $40^{\circ} \mathrm{C}$, the relative contribution of the CAM pathway to total $\mathrm{CO}_{2}$ uptake, was greater for pineapple grown at elevated than at ambient $\mathrm{CO}_{2}$.

The TA values obtained at the end of phases I and IV were significantly greater for plants grown at elevated than at ambient $\mathrm{CO}_{2}$, but the differences in the values for phase IV were small (Table 3). The diurnal difference in TA $(\triangle T A)$ between phase I and IV, a measure of net $\mathrm{CO}_{2}$ dark fixation (Griffiths, 1988), also was significantly greater for plants grown at elevated than at ambient $\mathrm{CO}_{2}$ (Table 2). Thus, the TA data are completely consistent with the data for carbon isotope discrimination $(\Delta)$ (Fig. 1). The results of this study are not consistent with those for pineapple grown at lower temperatures (Zhu, 1996), and some other species having CAM, which showed that elevated $\mathrm{CO}_{2}$ enhances $\mathrm{CO}_{2}$ fixation primarily via $\mathrm{C}_{3}$ pathway (Nobel and Hartsock, 1986; Szarek et al., 1987). Nocturnal carbon assimilation mediated by phosphoenolpyruvate carboxylase (PEPCase) was reported to be insensitive to $\mathrm{CO}_{2}$ enrichment (Bowes, 1991; Winter, 1985) because it was assumed that carboxylation by PEPCase was saturated at ambient $\mathrm{CO}_{2}$ levels. However, it is clear from this and some other studies (Nowak and Martin, 1995; Zhu, 1996) that phase- $\mathrm{I} \mathrm{CO}_{2}$ assimilation by PEPCase in pineapple leaves was not $\mathrm{CO}_{2}$ saturated at ambient $\mathrm{CO}_{2}$ levels. The enhancement of $\mathrm{CO}_{2}$ dark fixation by elevated $\mathrm{CO}_{2}$ could be due to one or more factors: 1) elevated $\mathrm{CO}_{2}$ might help to offset the effect of low leaf conductance, which could limit the rate of $\mathrm{CO}_{2}$ transport to the site of fixation, 2) PEPCase in pineapple might not be $\mathrm{CO}_{2}$ saturated at ambient $\mathrm{CO}_{2}$ concentrations, or 3) dark respiration could be reduced at elevated $\mathrm{CO}_{2}$ (Amthor, 1991; Nobel and Israel, 1994).

Osmolarity at the end of phases I and IV were significantly higher at elevated than at ambient $\mathrm{CO}_{2}$, with a greater effect for the phase I measurement (Table 3 ). The greater osmolarity at elevated $\mathrm{CO}_{2}$ in phase $\mathrm{I}$ is attributable primarily to the higher nocturnal organic acid levels (Medina et al., 1991, 1993; Zhu, 1996). The greater osmolarity in phase IV for plants grown at elevated $\mathrm{CO}_{2}$ may result from a greater accumulation of assimilates, such as soluble sugars, in leaf tissues (Medina et al., 1993). Soluble sugars are a major carbohydrate storage pool in pineapple leaves and reach their maximum level near the end of phase IV (Carnal and Black, 1989).

The percent total $\mathrm{N}$ in $\mathrm{D}$ leaves was not significantly different between treatments (1.28 in ambient and 1.20 in elevated $\mathrm{CO}_{2}$ ), and D-leaf chlorophyll in the same two treatments was 3.83 and $4.03 \mu \mathrm{mol} \cdot \mathrm{m}^{-2}$ (difference also was not significant). The lack of a significant effect of elevated $\mathrm{CO}_{2}$ on the leaf $\mathrm{N}$ and chlorophyll contents in this experiment was in contrast to the results obtained earlier (Zhu, 1996). We attribute the different responses in the two studies to improved nutrient management in this study, as a result of using a specially prepared nutrient solution and more frequent application of nutrients to the plants. Leaf chlorophyll and $\mathrm{N}$ contents decreased for $O$. ficus-indica after plants had been grown at elevated $\mathrm{CO}_{2}$ for $\approx 3$ months (Cui and Nobel, 1994). Leaf $\mathrm{N}$ content also declined as $\mathrm{CO}_{2}$ increased for some $\mathrm{C}_{3}$ plants (Rowland- 
Bamford et al., 1991; Tissue et al., 1993; Wong, 1990) and the $\mathrm{C}_{4}$ species Amaranthus retroflexus (Coleman et al., 1991). Most of those reports clearly stated that the nutrients applied were sufficient to prevent $\mathrm{N}$ deficiency. Our results indicate that, with careful nutrient management and adequate rooting volume, long-term exposure to elevated $\mathrm{CO}_{2}$ did not reduce leaf $\mathrm{N}$ or chlorophyll contents if complete nutrients were applied twice weekly. Further investigation may be needed to understand the fundamental cause of the decrease in tissue $\mathrm{N}$ and chlorophyll contents in response to elevated $\mathrm{CO}_{2}$ reported in some studies.

Our results show that pineapple growth was enhanced after 4 months of exposure to elevated $\mathrm{CO}_{2}$, even with a high day temperature. Furthermore, the $\Delta$ and TA data demonstrated unequivocally that this enhancement was mainly the result of greater nocturnal $\mathrm{CO}_{2}$ fixation. These data and those obtained previously in controlled environments (Zhu, 1996) indicate that even if global warming results in a significant temperature increase in the tropics, dry matter accumulation by pineapple should be significantly enhanced by elevated $\mathrm{CO}_{2}$.

\section{Literature Cited}

Acock, B. 1990. Effects of carbon dioxide on photosynthesis, plant growth, and other processes, p. 45-60. In B.A. Kimball, N.J. Rosenberg, and L.H. Allen, Jr. (eds.). Impact of carbon dioxide, trace gases, and climate change on global agriculture. ASA Special Pub. 53. Amer. Soc. Agron., Madison, Wis.

Amthor, J.S. 1991. Respiration in a future, higher- $\mathrm{CO}_{2}$ world. Plant Cell Environ. 14:13-20.

Aubert, B. and D.P. Bartholomew. 1973. Mesures en champ de la température de limbes d'ananas par radiométrie infrarouge. Fruits 28:623-629.

Bartholomew, D.P. 1982. Environmental control of carbon assimilation and dry matter production by pineapple, p. 278-294. In: I.P. Ting and M. Gibbs (eds.).Crassulacean acid metabolism. Amer.Soc.PlantPhysiol.Rockville, Md.

Bartholomew, D.P and S.B. Kadzimin. 1977. Pineapple, p. 113-156. In: P. de T. Alvim and T.T. Kozlowski (eds.). Ecophysiology of tropical crops. Academic, New York.

Bartholomew D.P. and R. Paull. 1986. Pineapple, p. 371-388. In: S.P. Monselise (eds.). CRC Handbook of fruit set and development. CRC Press, Boca Raton, Fla.

Bartholomew, D.P. and E. Malézieux. 1994. Pineapple, p. 243-291. In: B. Schaffer and P.C. Anderson (eds.). Handbook of environmental physiology of fruit crops, vol. II, CRC Press, Boca Raton, Fla.

Black, C.C., Jr. 1986. Effects of $\mathrm{CO}_{2}$ concentration on photosynthesis and respiration of $\mathrm{C}_{4}$ and CAM plants, p. 29-40. In H.Z Enoch and B.A. Kimball (eds.). Physiology, yield, and economics. vol. II. Carbon dioxide enrichment of greenhouse crops. CRC Press, Boca Raton, Fla.

Bowes, G. 1991. Growth at elevated $\mathrm{CO}_{2}$ : Photosynthetic responses mediated through rubisco. Plant Cell Environ. 14:795-806.

Carnal, N.W. and Black, C.C. 1989. Soluble sugars as the carbohydrate reserve for CAM in pineapple leaves. Implications for the role of pyrophosphate 6-phosphofructokinase in glycolysis. Plant Physiol. 90:91-100.

Chiariello N.R, H.A. Mooney, and K. Williams. 1989. Growth, carbon allocation and cost of plant tissues, p. 327-365. In: R.W Pearcy, J.R. Ehleringer, H.A. Mooney, and P.W. Rundel (cds.). Plant physiological ecology: Field methods and instrumentation. Chapman and Hall, London. Coleman, J.S., L. Rochefort, F.A. Bazzaz, and F.I. Woodward. 1991. Atmospheric $\mathrm{CO}_{2}$, plant nitrogen status and the susceptibility of plants to an acute increase in temperature. Plant Cell Environ. 14:667-674.

Coombs, J., G. Hind, R.C. Leegood, L.L. Tieszen, and A. Vonshak. 1985 Analytical techniques, p. 219-228. In: J. Coombs, D.O Hall, S.P. Long, and J.M.O. Scurlock (eds.). Techniques in bioproductivity and photosynthesis. 2nd ed. Pergamon Press, Oxford.

Cote, F.X., M. Folliot, and M. Andre. 1993. Photosynthetic Crassulacean acid metabolism in pineapple: Diel rhythm of $\mathrm{CO}_{2}$ fixation, water use, and effect of water stress. Acta Hort. 344:113-129.

Cui, M.,P.M. Miller, and P.S. Nobel. 1993. $\mathrm{CO}_{2}$ exchange and growth of the Crassulacean acid metabolism plant $O$ puntia ficus-indica under elevated
$\mathrm{CO}_{2}$ in open-top chambers. Plant Physiol. 103:519-524.

Cui, M. and P.S. Nobel. 1994. Gas exchange and growth responses to elevated $\mathrm{CO}_{2}$ and light levels in the CAM species Opuntia ficus-indica. Plant Cell Environ. 17:935-944.

Griffiths, H. 1988. Crassulacean acid metabolism: A re-appraisal of physiological plasticity in form and function. Adv. Bot. Res. 15:43-92.

Griffiths, H. 1992. Carbon isotope discrimination and the integration of carbon assimilation pathway in terrestrial CAM plants. Plant Cell Environ. 15:1051-1062.

Guralnick, L.J., R.L. Heath, G. Goldstein, and I.P. Ting. 1992. Fluorescence quenching in the varied photosynthetic modes of Portulacaria afra (L.) Jacq. Plant Physiol. 99:1309-1313.

Idso, S.B., B.A. Kimball, M.G. Anderson, and S.R. Szarek. 1986. Growth response of a succulent plant, Agave vilmoriniana, to elevated $\mathrm{CO}_{2}$. Plant Physiol. 80:796-797.

Jones, H.G. 1992. Plants and microclimate: A quantitative approach to environmental plant physiology. 2nd ed. Cambridge Univ. Press, Cambridge.

Krause, G.H. 1991. Chlorophyll fluorescence and photosynthesis: the basics. Annu. Rev. Plant Physio. Plant Mol. Biol. 42:313-349.

Medina, E., M. Popp, U. Lüttge, and E. Ball. 1991. Gas exchange and acid accumulation in high and low irradiance grown pineapple cultivars. Photosynthetica 25:489-498.

Medina, E., M. Popp, E. Olivares, H.P. Janett, and U. Lüttge. 1993. Daily fluctuations of titratable acidity, content of organic acids (malate and citrate) and soluble sugars of varieties and wild relatives of Ananas comosus L. growing under natural tropical conditions. Plant Cell Environ. 16:55-63.

Nobel P.S. and T.L. Hartsock. 1986. Short-term and long-term responses of Crassulacean acid metabolism plants to elevated $\mathrm{CO}_{2}$. Plant Physiol. 82:604-606.

Nobel, P.S. and A. Israel. 1994. Cladode development, environmental responses of $\mathrm{CO}_{2}$ uptake, and productivity for Opuntia ficus-indica under elevated $\mathrm{CO}_{2}$. J. Expt. Bot. 45:295-303.

Noffsinger, T.L. 1961. Leaf and air temperatures under Hawaiian conditions. Pacific Sci. 15:304-306.

Nowak, E.J. and C.E. Martin. 1995. Effect of elevated $\mathrm{CO}_{2}$ on nocturnal malate accumulation in the CAM species Tillandsia ionantha and Crassula arborescens. Photosynthetica 31:441-444.

Osmond, C.B. 1978. Crassulacean acid metabolism: A curiosity in context. Ann. Rev. Plant Physiol. 29:379-414.

Raveh, E., M. Gersani, and P.S. Nobel. 1995. $\mathrm{CO}_{2}$ uptake and fluorescence responses for a shade-tolerant cactus Hylocereus undatus under current and doubled $\mathrm{CO}_{2}$ concentrations. Physiol. Plant. 93:505-511.

Rowland-Bamford, A.J., J.T. Baker, L.H. Allen, Jr., and G. Bowes. 1991. Acclimation of rice to changing atmospheric carbon dioxide concentration. Plant Cell Environ. 14:577-583.

Sarmiento, J.L and M. Bender. 1994. Carbon biogeochemistry and climate change. Photosynth. Res. 39:209-234.

Szarek, R.S, P.A. Holthe, and I.P. Ting. 1987. Minor physiological response to elevated $\mathrm{CO}_{2}$ by the CAM plant Agave vilmoriniana. Plant Physiol. 83:934-940.

Tissue, D.T., R.B. Thomas, and B.R. Strain. 1993. Long-term effects of elevated $\mathrm{CO}_{2}$ and nutrients on photosynthesis and rubisco in loblolly pine seedlings. Plant Cell Environ. 16:859-865.

Winter, K. 1985. Crassulacean acid metabolism, p. 330-387. In: J. Barker and N.R. Baker (eds.). Photosynthetic mechanisms and the environment. Elsevier Science Publishers, Amsterdam.

Wong, S.C. 1990. Elevated atmospheric partial pressure of $\mathrm{CO}_{2}$ and plant growth. II. Non-structural carbohydrate content in cotton plants and its effect on growth. Photosynth. Res. 23:171-180.

Zhu, J. 1996. Physiological responses of pineapple (Ananas comosus (L.) Merr.), A species having Crassulacean acid metabolism (CAM), to $\mathrm{CO}_{2}$ enrichment, temperatures and water deficit. PhDDiss., Dept. of Agronomy and Soil Science, Univ. of Hawaii at Manoa, Honolulu.

Zhu, J., D.P. Bartholomew, and G. Goldstein. 1997. Effects of temperature, $\mathrm{CO}_{2}$, and water stress on leaf gas exchange and biomass accumulation of pincapple. Acta Hort. 425. (In press.) 